ElementerIs: Jurnal Ilmiah Pendidikan Dasar Islam

Volume 2 Nomor 2 November 2020

e-ISSN: 2655-6324

\title{
STRATEGI KEPALA MADRASAH DALAM MENENTUKAN KEBIJAKAN PEMBELAJARAN ERA COVID 19: STUDI KASUS KEPALA MADRASAH IBTIDAIYAH NW PONDOK GEDANG
}

\author{
Muhammad Sufyan Ats-Tsauri ${ }^{1}$, Erni Munastiwi ${ }^{2}$ \\ Pascasarjana Universitas Islam Negri Sunan Kalijaga Yogyakarta \\ e-mail: ${ }^{1}$ sufyanatstsauri96@gmil.com , 2abababab@mail.com
}

Diterima: 5 September 2020 I Direvisi: 7 Oktober 2020 I Disetujui: 2 November 2020 (C) 2020 Pendidikan Guru Madrasah Ibtidaiyah Fakultas Agama Islam Universitas Islam Malang

\begin{abstract}
Learning policies in the pandemic era made by the principal must be able to create an effective and efficient learning atmosphere. This study aims to look at the strategy of the head of the Madrasah Ibtidayah NW Pondok Gedang in determining learning policies in the pandemic era. This research uses a qualitative approach. The data technique used was interview, observation and documentation. Data analysis was performed by data reduction, data display and data retrieval. The results of this study are that the strategies adopted by the principal in implementing learning in the pandemic era are (1) determining, determining, compiling, and implementing learning during the pandemic period which has a great opportunity to achieve learning objectives, (2) providing understanding to teachers and Students regarding courageous learning, (3) adding activities that can be practiced directly, and (4) carrying out student responsibilities, so that they can be carried out as usual by teachers in schools. Thus, the head of madrasa adopted a learning policy that could be implemented boldly through platforms and social media during the pandemic.
\end{abstract}

Keyword: strategies, principals, pandemic times, case studies

\begin{abstract}
Abstrak
Kebijakan pembelajaran di era pandemi yang dibuat oleh kepala madrasah seharusnya bisa menciptakkan suasana pembelajaran yang efektif dan efesien. Penelitian ini bertujuan untuk mengetahui strategi kepala Madrasah Ibtidayah NW Pondok Gedang dalam menentukan kebijakan pembelajaran di era pandemi. Penelitian ini menggunakan pendekatan kualitatif. Teknik pengumpulan data yang digunakan yaitu dengan wawancara, observasi dan dokumentasi. Analisis data dilakukan dengan reduksi data, display data dan penarikan kesimpulan. Hasil dari penelitian ini yaitu bahwa strategi yang dilakukan kepala madrasah dalam
\end{abstract}

This work is licensed under Creative Commons Attribution Non Commercial 4.0 International 
menerapkan pembelajaran di era pandemi yaitu (1) merancang, menentukan, menyusun, dan mengimplementasikan pembelajaran dimasa pandemi yang mempunyai kesempatan besar untuk tercapainya sebuah tujuan pembelajaran, (2) memberikan pemahaman kepada guru dan siswa mengenai mekanisme pembelajaran daring, (3) menambah kegiatan yang dapat diperaktikkan secara lansung dirumah, serta (4) melaksanakan penilaian siswa secara daring, sehingga dapat dilaksanakan seperti biasanya oleh guru di sekolah. Dengan demikian kepala madrasah mengambil kebijakan pembelajaran yang dapat dilaksanakan secara daring melalui platform dan media sosial selama pandemi.

Kata kunci: strategi, kepala sekolah, masa pandemi, studi kasus

\section{Pendahuluan}

Pendidikan pada hakikatnya adalah sebuah proses untuk menyiapkan manusia agar dapat mengembangkan kemampuan dan membentuk watak serta peradaban dalam rangka mencerdaskan kehidupan bangsa. Pendidikan juga diharapkan dapat menghasilkan peserta didik yang unggul dan memiliki iman yang tinggi. Pendidikan yang baik diharapkan dapat memberikan implikasi yang berfokus pada proses pengembangan individu sesuai dengan nilai-nilai agama dan kehidupan yang dianutnya. Untuk mewujudkan hakikat, fungsi, dan tujuan pendidikan tersebut maka perlu didukung dengan beberapa hal seperti kurikulum yang adaptif, pendidikan yang profesional, sarana prasarana yang memadai serta dukungan penuh dari pemerintah dan masyrakat. Selain itu pembelajaran juga dapat memanfaatkan modul untuk meningkatkan keterampilan berpikir kritis siswa (Khairiyah \& Faizah, 2019) dan perlu di desain secara kreatif, menantang, dan memberikan ruang bagi siswa untuk berkreasi (Munir \& Sholehah, 2019).

Sejak pemerintah mengumumkan mengenai kasus pertama corona virus desease 2019 (covid 19) pada bulan maret 2020 yang lalu, Indosenia dihadapakan pada masa pandemi. Hampir seluh sektor kehidupan terdampak tidak terkecuali disektor pendidikan. Pada aspek pendidikan, pemerintah melalui Kementerian Pendidikan dan Kebudayaan (Kemendikbud) telah menerapkan kebijakan learning for home atau belajar dari rumah, terutama bagi satuan pendidikan yang berada di wilayah zona kuning, merah dan hitam. Bagi satuan pendidikan yang berada di zona hijau, dapat melaksanakan pendidikan dengan mengarah kepada protokol kesehatan.

Berdasakan fenomena tersebut suasana dan proses pendidikan mengalami perubahan, perubahan tersebut dilatarbelakangi oleh maraknya wabah covid 19 sehingga menjadi kendala terjalinnya hubungan sosial maupun emosional secara lansung dalam pendidikan di Indonesia. Pandemi covid 19 diharapkan tidak 
membuat pelaksanaan pendidikan kita terkendala, mengingat bantuan teknologi hari ini dapat mendukung terciptanya pelaksanaan pembelajaran dengan siswa. Guru juga dapat menerapkan metode hypnoteaching untuk meningkatkan motivasi belajar siswa (Sari, Saadati \& Sadl, 2019) dengan tetap mengikuti anjuran pemerintah untuk menerapkan protokol kesehatan pada era pandemi covid 19 (Taufan \& Fachri, 2014).

Dalam sebuah lembaga pendidikan, kepala madrasah memiliki peran penentu sebuah kebijakan yang strategis. Kepala madrasah merupakan pimpinan dalam oragnisasi tersebut, kepala sekolah sebagai kunci pendorong bagi perkembangan dan kemajuan sekolah. Kepala madrasah juga bertanggung jawab untuk meningkatkan keberhasilan siswa dan program-program di sekolah. Agar hal tersebut tercapai dengan baik maka kepala sekolah dalam menentukan sebuah kebijkan di era pandemi covid 19 harus dengan pertimbangan yang tepat. Hal tersebut tentu akan berpengaruh terhadap kegiatan pembelajaran yang ada di sekolah, maka dalam hal ini kepala sekolah diharapkan mampu berperan sesuai dengan tugas, wewenang, dan tanggung jawabnya (Khadijah, 2015), karena untuk mencapai pembelajaran yang optimal tidak terlepas dari kebijakan pemerintah dan kebijakan kepela sekolah.

Kebijakan (policy) seringkali diterjemahkan atau dikaitkan dengan kepentingan politik, aturan, program, keputusan, undang-undang, peraturan, ketentuan, kesepakatan, konvensi, dan rencana strategis lainnya (Arwildayanto, Suking \& Sumar, 2018). Kebijakan pemerintah merupakan landasan dasar pada kebijakan belajar di satuan-satuan pendidikan lainnya, sehingga menyangkut kebijakan tersebut kepala sekolah memiliki otoritas dalam mengambil kebijakan proses pembelajaran yang harapannya tujuan pembelajran dapat terealisasikan dengan baik dan optimal. Strategi dalam menentukan kebijakan adalah suatu hal yang harus dikembangkan oleh setiap kepala lembaga pendidikan dalam sebuah organisasi, dimana strategi tersebut dapat digunakan untuk menentukan kebijakan yang strategis (Praherdhiono, dkk, 2020). Dalam penelitian ini akan dibahas bagaimana strategi kepala Madrasah Ibtidaiyah NW Pondok Gedang dalam menentukan kebijakan pembelajaran pada era pandemi covid 19, agar pembelajaran berjalan dengan baik dan optimal.

\section{Metode}

Metode penelitian ini menggunakan penelitian dalam pendekatan kualitatif dan menggunakan jenis atau metode deskrptif (Wina, 2013). Penelitian ini mendeskripsikan tentang bagaiamana strategi kepala madrasah ibtidaiyah dalam 
menentukan kebijakan pembelajaran pada era pandemi covid 19. Teknik pengumpulan data yang digunakan adalah wawancara, observasi, dan dokumentasi. Teknik wawancara yang digunakan yaitu teknik wawancara tak terstruktur. Teknik observasi dilakukan dengan cara mengobservasi strategi kebijakan pembelajaran daring. Sedangkan teknik dokumentasi digunakan pada pencarian dokumen-dokumen yang berkaitan dengan strategi kepala sekolah dalam menentukan kegiatan belajar mengajar disekolah. Teknik analisis data menggunakan reduksi data, display data dan penarikan kesimpulan.

\section{Hasil dan Pembahasan}

Strategi adalah suatu cara atau teknik yang digunakan oleh seorang dalam hal apapun untuk mencapaai sebuah target dalam hal ini kontekstualisasi strategi dalam sebuha pemimpin adalah untuk mencapai tujuan yang diinginkan. Strategi dapat juga diartikan sebagai kiat, cara, mekanisme seorang pemimpin untuk mencapai tujuan dalam kepemimpinananya (Saiful \& Munip, 2017). Selanjutnya mengemukan strategi adalah rencana yang disatukan, memperluas dan terintegrasi yang menghubungkan keunggulan strategis perusahaan dengan tantangan lingkungan dan yang dirancang untuk memastikan bahwa tujuan utama dari perusahaan itu dapat dicapai melalui pelaksanaan yang tepat oleh organisasi manajemen strategis dalam sejumlah keputusan dan tindakan yang mengarah pada penyusunan suatu strategi atau sejumlah strategi yang efektif untuk membantu mencapai sasaran perusahaan (Jauch, 2000). Proses manajemen strategis ialah cara dengan jalan mana para perencanan strategis menentukan sasaran dan mengambil kebijakan.

Dapat diambil sebuah pengertian strategi dalam kepempinan kepala sekolah adalah suatu kiat, metode, meknisme dalam mengambil kebijakan dan menjalakan sebuha kebijakan sehingga target pencapaian dapat tercapai dengan maksimal berdasarkan strategi yang digunakan oleh lembagam sekolah atau madrasah pada umunya. Berdasarkan hasil observasi wawancara dan dokumentasi yang dilakukan dalam penelitian ini bahwasanya strategi kepala sekolah dalam mengambil kebijakan pembelajaran dimasa pandemi adalah:

\section{Merancang, menentukan, menyusun, dan mengimplementasikan pembelajaran untuk mencapai tujuan pembelajaran}

Dalam upaya kepala sekolah membuat sebuah kebijakan pembelajaran terungkap dengan beberapa hasil wawancara yaitu dengan HS yang mengatakan bahwa" agar pembelajaran dimasa pandemi ini dapat berjalan dengan baik, kami dari Lembaga sekolah akan menyususn strategi belajar diluar kelas baik itu dirumah 
dan di tempat-tempat tertentu dengan berkelompok-kelompok, selain itu strategi belajar yang akan kita gunakan adalah dengan memanfaatkan media social sehingga siswa dengan guru dapat berkomunikasi secara lansung media social sehingga pembelajaran dapat berjalan sebagaimana yang kita harapkan". Dari wawancara ini bahwasanya strategi yang dilakukan untuk menerapkan pembelajaran dimasa pandemi yaitu dengan Menyusun kelompok-kelompok belajar yang dilaksankan diluar sekolah. Kemudian selanjutnya guru dan siswa memanfaatkan media sosial sebagi media pembelajaran untuk memudahkan pembelajaran jarak jauh antara siswa dengan guru dan siswa dengan siswa lainnya.

Dalam perencanaan starategi diera pandemi yang sudah dibuat oleh kepala sekolah adalah persiapan perencanaan strategi dalam pembelajaran daring keoada peserta didik denga menggunakan alat media sosial sebagai sarana pembelajaran serta pola pembelajarannya didasarkan pada tujuan yang diharapkan dimana tujuan pembelajaran adalah selain untuk meningkatkan pengetahuan peserta didik juga bisa merubah kebiasaan atu tingkah laku peserta didik hal ini sesuai dengan pernyataan kimble dan garmezi tentang pengertian belajar bahwasanya belajar merupakan perubahan tingklah ; aku yang bersikap tetap yang berlansung dari pengalaman oleh karena itu persiapan yang disusun oleh sekolah hendaknya disesuiakan dengan keadaan dan situasi sekarang ini.

\section{Memberikan pemahaman kepada guru dan siswa mengenai mekanisme pembelajaran daring}

Implmentasi pembelajaran daring mengacu kepada kebijakan dan peraturan pemerintah dan kebijakan kepala sekolah menganai pembelajaran daring. Dalam situasi dan kondisi yang terjadi saat ini masa pandemic bukanlah menjadi kendala pelaksanaan proses belajar mengajar. Namun bagaiamana kita mampu membaca situasi dan memanfaatkan media sosial sebagi media pembelajaran sehingga pembelajaran dimasa pandemi ini tetap terlaksana seuai tujuan pembelajaran yang diharapakan. Dalam mengimplementasikan pembelajaran daring guru atau tenaga pendidik juga harus memberikan pemahaman kepada peserta didik agar pembelajaran daring yang dilaksanakan sesuai dengan peraturan protokol Kesehatan.

\section{Menambah kegiatan yang sifatnya dapat diperaktikkan secara lansung dirumah}

Disamping pembelajaran yang sifatnya tertulis dan disertai tugas-tugas belajar peserta didik guru dapat memberikan tugas tambahan yang sifatnya 
praktik, contohnya pada pembelajaran Qur'an Hadits yaitu peserta didik diminta untuk membuat video pendek membaca surat-surat pendek dalam Al Qur'an.

\section{Penilaian siswa dalam pelaksanaan pembelajaran daring, menggunakan penilaian lapangan yang bersifat kualitaif yaitu penilaian yang sifatnya membangun motivasi belajar siswa disekolah}

Hal terpenting adalah siswa dijleaskan pembelajaran daring terjadi dilatar belakangi terkait pandemi covid 19 (Meiza, dkk, 2020). Jadi dalam arti dekat yang dimaksud strategi dalam penulisan ini adalah suatu cara atau kiat-kiat tertentu yang diterapkan oleh kepala sekolah/kepala madrasah untuk mencapai tujuan dari organisasi sekolah. Sedangkan Akdon (2007) mengemukakan bahwa strategi adalah kerangka yang membimbing pilihan yang menetapkan sifat dan arah suatu organisasi baik organisasi kemasyarakatan atau organisasi perusahaan serta aktifitas mengerjakan sesuatu yang benar (doing the right things).

\section{Simpulan}

Berdasarkan uraian tersebut peneliti dapat mengambil kesimpulan bahwa strategi kepala sekolah dalam menerapkan pembelajaran di era pandemi melalui proses pembelajaran daring di MI NW Pondok Gedang Desa Aik Berik Kecamatan Batukliang Utara Kabupaten Lombok Tengah Provinsi NTB sudah dilakukan dengan baik yaitu dengan beberapa cara seperti (1) merancang, menentukan, menyusun, dan mengimplementasikan pembelajaran di masa pandemi yang memiliki peluang besar untuk tercapainya sebuah tujuan pembelajaran, (2) memberikan pemahaman kepada guru dan siswa mengenai mekanisme pembelajaran daring, (3) menambah kegiatan yang sifatnya dapat diperaktikkan secara langsung dirumah, serta (4) penilaian siswa dalam pelaksanaan pembelajaran daring, tidak hanya dinilai seperti biasanya namun lebih bervariasi. Dengan demikian kepala Madrasah Ibtidiyah Pondok Gedang membuat kebijakan dengan memperhatikan kebijakan dari pemerintah dan juga memperhatikan situasi, kondisi, serta perkembangan pandemic covid 19 di Indonesia.

\section{Daftar Rujukan}

Akdon. 2007. Strategic Management for Educational Management (Manajemen Strategik Untuk Manajemen Pendidikan). Bandung: CV Alfabeta.

Arwildayanto, Suking, Arifin \& Sumar, Warni T. 2018. Analisis Kebijakan Pendidikan Kajian Teoretis Eksploratif dan Aplikatif. Bandung: CV Cendekia Press.

Jauch, Lawrence R. 2000. Manajemen Strategis Dan Kebijakan Perusahaan. Jakarta: 


\section{Erlangga.}

Khadijah, Ifah. 2015. Manajemen Mutu Terpadu (Tqm) Pada Lembaga Pendidikan Islam. https://doi.org/10.24042/alidarah.v5i1.754.

Khairiyah, Ummu \& Faizah, Silviana Nur. 2019. Respon Siswa Terhadap Penggunaan Modul Tematik Dalam Meningkatkan Kemampuan Berpikir Kritis. Malang: Elementeris: Jurnal Pendidikan Dasar Islam. Volume 2 Nomor 1. DOI: http://dx.doi.org/10.33474/elementeris.v2i1.4903

Meiza, Asti, Hanifah, Fithria Siti, Natanael, Yonathan \& Nurdin, Farid S. 2020. Analisis Regresi Ordinal untuk melihat Pengaruh Media Pembelajaran Daring terhadap Antusiasme Mahasiswa Era Pandemi Covid. Bandung: Program Studi Psikologi UIN Sunan Gunung Djati Bandung.

Munir, Muhammad \& Sholehah Hijriati. 2019. Metode Pembelajaran Dengan Pendekatan Discovery Learning Dalam Mengembangkan Kemampuan Berpikir Kreatif. Malang: Elementeris: Jurnal Pendidikan Dasar Islam. Volume 1 Nomor 2. DOI: http://dx.doi.org/10.33474/elementeris.v1i2.4786

Praherdhiono, Henry, Adi, Eka Pramono, Prihatmoko, Yulias, Nindigraha Nunung, Soepriyanto Yerry, Indreswari Henny \& Oktaviani, Herlina Ike. 2020. Implementasi Pembelajaran Di Era Dan Pasca Pandemi Covid-19. Malang: CV Seribu Bintang.

Rizal, Syaiful \& Munip, Abdul. 2017. Strategi Guru Kelas dalam Mumbuhkan Nilainilai Karakter Pada Peserta Didik (Study Kasus: SDN Pondok Dalem 01 Semboro dan MI Fathus Salafi Ajung Jember). Al Ibtida: Jurnal Pendidikan Guru MI Vol. 4, No. 1 (Juni 19, 2017): 45. https://doi.org/10.24235/al.ibtida.snj.v4i1.1462.

Sanjaya, Wina. 2013. Penelitian Pendidikan Jenis, Metode Dan Prosedur. Jakarta: Kencana Prenada Media Group.

Sari, Buana, Saadati, Baiq Arnika, Sadl, Muhamad. 2019. Penigkatan Motivasi Belajar Siswa Melalui Penerapan Metode Hypnoteaching Pada Mata Pelajaran IPS Siswa Kelas V SD Nurul Ijtihad Putut Lombok Tengah. Malang: Elementeris: Jurnal Pendidikan Dasar Islam. Volume 1 Nomor 2. DOI: http://dx.doi.org/10.33474/elementeris.v1i2.4872

Taufan, Johandri, and Fachri Mazhud. 2014. Kebijakan-Kebijakan Kepala Sekolah Dalam Penyelenggaraan Pendidikan Inklusif Di Sekolah X Kota Jambi. JPP: Jurnal Penelitian Pendidikan Vol. 14 No. 1. 